\title{
DANIEL 6:20: AN ARAMAIC CALQUE ON AN AKKADIAN EXPRESSION*
}

\author{
Shalom M Paul \\ Bible Department, Hebrew University \\ Jerusalem
}

\begin{abstract}

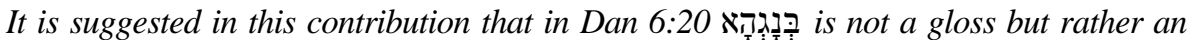
Aramaic calque on the Akkadian expression, ina/ana mimmû šêri ina namāri, "When the first light of dawn shone," which occurs several times in the Gilgamesh epic, tablets VI:88; VIII:1, 64, 90, 206; XI:48, 97, which is comprised of the Akkadian verb, namāru, "to dawn, shine brightly," and the noun, šerru (= נ]), "daybreak, daylight." There is also the possibility that the word

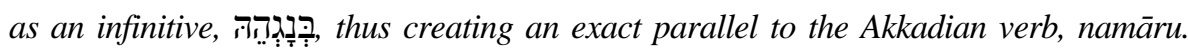
This, then, would add yet another example to the multiple influences of Akkadian words and phrases upon the Aramaic of the book of Daniel.
\end{abstract}

In Chapter 6 of the book of Daniel, which pertains to the miraculous rescue of Daniel from the lions' den, it is reported that the king, perturbingly pondering Daniel's precarious position, spent a sleepless night (vs. 19), ${ }^{1}$ and "at the very break of dawn's first light hurriedly arose" to see

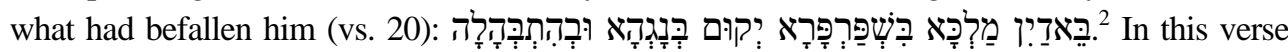

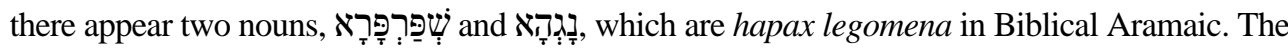


then with a majuscule $פ$ ), is formed by a reduplication of the last two consonants of a tri-

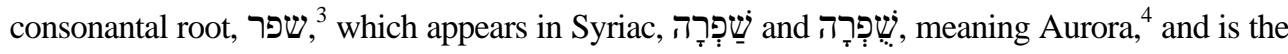
interdialectal etymological equivalent of Arabic سفر (safara), "to shine," referring to the dawn

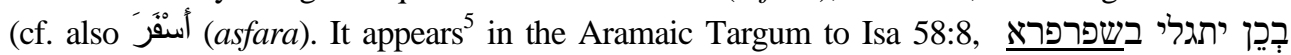

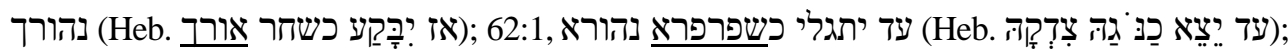

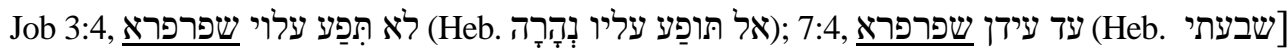

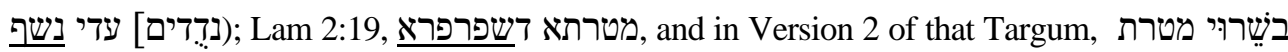
(Heb. בראש אשמְרות); and also in an appendix at the end of the book of Esther (10:3)

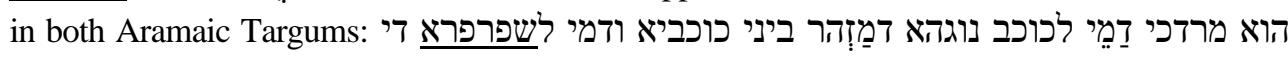

* To Yeshoshua Gitay, friend and colleague.

1. Compare the similar motif and wording in Esth 6:1.

2. In 4QDan ${ }^{b}$, the reading is: באדין מל[כא בשפרפ]רא בנגהא ובאתבה [לה. According to the spacing, it is apparent that יקום was omitted. See Ulrich E et al., Qumran Cave 4·XI: Psalms to Chronicles, DJD 16 (Oxford, 2000), 261-262.

3. Compare similarly, e.g., שדמדם, Lev 13:42; 14:49; החרח רת, Song of Songs 1:6; הפכפרפ, Prov 21:8; Isa 2:20. See Kautsch, E and Cowley, AE, Gesenius' Hebrew Grammar ${ }^{2}$ (Oxford, 1957), 234-235, 84b.

4. Dalman, G, Aramäisch-neuhebräische Handwörterbuch ${ }^{2}$ (Frankfurt am Main, 1922), 433a; Brockelmann, C, Lexicon Syriacum ${ }^{2}$ (Halle, 1928), 797a.

5. For citations, see Sperber, A, The Bible in Aramaic, III (Leiden, 1962), ad loc. (Hebrew). 
"He, Mordecai, is comparable to the planet Venus that shines amongst the stars and resembles the dawn that comes forth at morning time."

The second noun, נגהא, which is well attested not only in Biblical Hebrew both as a verb, "to shine," in the qal, Isa 9:1; Job 18:5; 22:28; and in the hiph 'il, 2 Sam 22:29 = Ps 18:29; Isa 13:10; and as a noun, "brightness, light of heavenly bodies," in the singular twenty times, e.g., Amos 5:20; Isa 50:12; 60:19; 62:1; Ezek 1:13; Hab 3:11 (compare also the Deir Alla inscription, first combination, lines 6-7: נגגה); ${ }^{7}$ and once in the plural, Isa 59:9; but also in Rabbinic Hebrew, ${ }^{8}$ designating, in addition, the planet Venus, כוכבא נוגהא (cf. the reference above to the two Targums to the book of Esther). ${ }^{9}$

Because of the unusual combination of these two synonymous nouns in one and the same verse, commentators have assumed that the second, בנגהא, functions as an Aramaic gloss which was inserted to clarify the rare substantive, בשפרפרא, similar to what has been suggested for

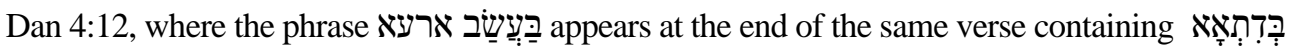
די ברא. This latter example, however, is most likely not a misplaced gloss (since there would be no reason to gloss this clearly understandable expression), but rather is an example of a textual doublet created by the preservation of two variant synonymous readings. ${ }^{10}$ It is here suggested

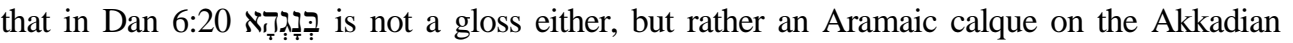
expression, ina/ana mimmû šeri ina namāri, "When the first light of dawn shone," which occurs several times in the Gilgamesh epic, tablets VI:88; VIII:1, 64, 90, 206; XI:48, 97, which is comprised of the Akkadian verb, namāru, "to dawn, shine brightly,"11 and the noun, šerru (= נ]), "daybreak, daylight." 12 Furthermore, if the reconstruction of the citation from Gilgamesh VIII:64 is correct: ina mimmû šêri ina namāri Gi[lgameš itbìma], "When the first light of dawn shone, Gi[lgamesh arose]," this would supply an exact cognate equivalent to our verse. ${ }^{13}$ In light

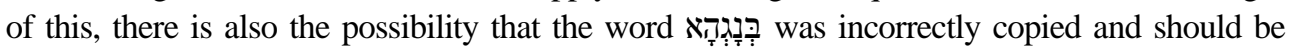

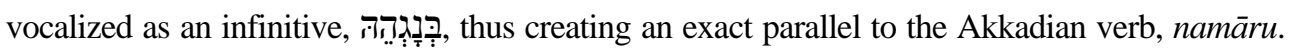
This, then, would add yet another example to the multiple influences of Akkadian words and phrases upon the Aramaic of the book of Daniel. ${ }^{14}$

6. The root appears both in Syriac, נוגדְה , and in the Ugaritic epic of Kirta (KTU $1.16 . \mathrm{I}: 37)$ : wtgh nir rbt, "the shining of the great light" (an epithet of the sun). See Pardee, D, "The Kirta Epic," in: Hallo, WW (ed.), The Context of Scripture, I (Leiden-New York-Köln, 1997), 340.

7. See Levine, BA, “The Deir- 'Alla Plaster Inscriptions," in: Hallo, WW (ed.), The Context of Scripture, II (Leiden-Boston-Köln, 2000), 143.

8. Sokoloff, M, A Dictionary of Jewish Palestinian Aramaic (Ramat Gan, 1990), 340; idem, A Dictionary of Jewish Babylonian Aramaic (Ramat Gan, 2002), 728-729; Jastrow, M, Dictionary of the Targumim, Talmud Babli, Yerushalmi and Midrashic Literature (New York, 1950), 872-873.

9. Jastrow, Dictionary, 619.

10. For textual doublets, see Tov, E, Textual Criticism of the Hebrew Bible (Minneapolis, 1992), 241-243.

11. CAD, N/I, 209-218. Compare also the noun form, namārītu, "dawn," ibid., 208.

12. $C A D, \breve{S} / I I, 331$.

13. For a citation from a neo-Babylonian text, without the substantive mimmû (literally, "any"): ina šeri ina namāri, see Lambert, WG, "Nebuchadnezzar King of Justice," Iraq 27 (1965), 6:26.

14. See Paul, SM, "The Mesopotamian Background of Daniel 1-6," in: Collins, JJ and Flint, PW (eds.), The Book of Daniel: Composition and Reception, I (Leiden-Boston-Köln, 2001), 55-68, with additional bibliography. After this article was submitted for publication, Dr. Sol Cohen brought to my attention further attestations of this substantive in Christian Palestinian Aramaic. See Duensing, $\mathrm{H}$, Christliche-Palästinisch-Aramäische Texte und Fragmente Göttingen 1906 (Jerusalem, 1971), 115; Kohut, A, Arukh ha-Shalem², VIII (Vienna, 1926), 139. 